Georgetown University Institutional Repository

http://www.library.georgetown.edu/digitalgeorgetown

Alonso, Sonia and Kaltwasser, Cristobal Rovira. 2014. Spain: No Country for the Populist Right? South European Society and Politics. doi: $\underline{10.1080 / 13608746.2014 .985448}$

Collection Permanent Link: hdl.handle.net/10822/712607

(C) 2014 Routledge

This material is made available online with the permission of the author, and in accordance with publisher policies. No further reproduction or distribution of this copy is permitted by electronic transmission or any other means. 


\title{
SPAIN: NO COUNTRY FOR THE POPULIST RADICAL RIGHT?
}

\author{
Sonia Alonso \& Cristóbal Rovira Kaltwasser ${ }^{1}$
}

\begin{abstract}
Although there is growing research interest in populist radical right parties in Western Europe, little attention has been paid to the case of Spain — a country where these parties are almost non-existent or irrelevant from an electoral and political point of view. In a nutshell, we maintain that in contemporary Spain there is real demand for populist radical right parties, but three supply-side factors are impeding their electoral breakthrough and persistence: the cleavage structure of the country, the strategy of competition of the mainstream right and the electoral system. At the same time, we postulate that at least in the case of Spain the Great Recession has not improved the electoral odds of the populist radical right as such but rather facilitated the emergence of leftist populist forces.
\end{abstract}

Keywords: Spain; cleavage structure; populism; anti-immigration; political parties; Southern Europe 


\section{SPAIN: NO COUNTRY FOR THE POPULIST RADICAL RIGHT?}

Since the beginning of 1980s the political landscape of Western Europe has been shaken by the emergence of a new party family: the populist radical right (PRR). Pundits and academics alike are inclined to observe this development with consternation, to the point that many see these parties as one of the main challenges faced by twenty-first century Western European democracy. After all, the PRR rallies against immigration and multiculturalism, supports welfare chauvinism and tends to be at odds with the process of European integration (Mudde 2007). So it is not surprising that this new party family has captured enormous academic and media attention (Bale 2012). Nevertheless, academic research on this topic has paid little attention to Spain—a country where populist radical right parties are almost non-existent despite the fact that there is growing political dissatisfaction with the political establishment and anti-immigrant attitudes are similar to those in other European countries with more successful PRR parties. In this article we are interested in showing that scholars can draw important lessons from a closer and more detailed look at the Spanish case.

This paper is structured in four sections. We begin by providing a brief clarification of the concept of PRR parties and, based on this definition, we offer evidence that, while present in most Western European countries, they are almost non-existent in Spain. The second section advances the theoretical argument of the paper and highlights the role that the existing cleavage structure of a society can play in hindering or facilitating the electoral fortune of PRR parties. After this, the third section provides empirical evidence to substantiate the theoretical argument and is divided in two parts. On the one hand, we explore the demand-side factors in order to show that there is real potential for the emergence of the PRR in Spain. On the other hand, we take into consideration

three supply-side factors - the Spanish electoral system, the electoral strategy of competition of the 
mainstream right and the cleavage structure of the country - to explain why this party family has not taken root in Spain. Finally, we conclude by discussing the implications of our findings in the Spanish case for analysing the PRR in Western Europe in general, and for studying the impact of the Great Recession on the political systems across Southern Europe in particular.

\section{The Spanish Populist Radical Right in its Wider Western European Context}

Nobody really doubts that PRR parties have taken root across Western Europe in the last three decades. However, there is an on-going debate about how to label them. Whereas some prefer the notion of 'anti-immigrant parties' (e.g. Art 2011), others adhere to the concept of 'radical right parties' (e.g. Norris 2005). In this paper we follow the definition developed by Mudde (2007), who has coined the concept of 'populist radical right parties'. This definition has several advantages over the alternatives. To begin with, this notion emphasises that we are not dealing with so-called singleissue parties. The electoral appeal of PRR parties is related not only to one driving idea (e.g. antiimmigration), but rather to a set of different ideas (e.g., ethnopluralism, populism, welfare chauvinism, etc.) which are combined in a way that turns out to be attractive for a section of the electorate of Western European countries. Moreover, Mudde's definition stresses that PRR parties are different from old or traditional far right parties: the former are (nominally) democratic, though

they are at odds with some aspects of liberal democracy, while the latter are simply anti-democratic and support the formation of an authoritarian government.

In addition, it is worth noting that Mudde's conceptual approach assumes that PRR parties share a core ideology that is characterised by three elements: authoritarianism, nativism and populism. The notion of authoritarianism alludes to the belief in a strictly ordered society and is 
expressed in the preference for 'law and order' issues (Mudde 2007, pp. 22-23). In turn, nativism refers to a combination of nationalism and xenophobia, in which a monocultural nation-state is the ideal and all non-natives (i.e. aliens) are perceived as threatening (ibid. 19). Finally, populism is conceived of as a 'thin-centred ideology that considers society to be ultimately separated into two homogenous and antagonistic groups, "the pure people" versus "the corrupt elite", and which argues that politics should be the expression of the volonté générale (general will) of the people' (Mudde 2004, p. 543). In summary, three elements—authoritarianism, nativism and populism—are the necessary and sufficient criteria to classify a specific party as a member of the populist radical right family.

Table 1 presents the electoral results of the most well-known examples of this party family from 1980 to 2014. Several aspects stand out in this figure. First, the electoral fortune of most of these parties varies across time. Contrary to alarmist reports in the media, the table shows that the PRR has not experienced continuous growth. Second, there is no homogenous pattern across Western Europe. While in some countries PRR parties have been gaining electoral power (e.g. Switzerland), in others they have been unsuccessful (e.g. United Kingdom). Third, and more relevant to this paper, there are only two countries in which PRR parties have never obtained more than one per cent of the vote in any national election: Portugal and Spain.

\section{(About here: table 1)}

In Spain there is a high level of fragmentation within the PRR party family. There are several parties that fit our definition and each represents a tiny fraction of the electorate. The PRR parties that appear most relevant are Democracia Nacional (National Democracy - DN), founded in 1995, 
España-2000 (Spain-2000 - E-2000), founded in 2002, and Plataforma per Catalunya (Platform for Catalonia - PxC), founded in 2002. DN and E-2000 are nation-wide parties, while PxC organises itself exclusively within the region of Catalonia. DN's ideological profile is characterised by a combination of anti-elitism and Spanish nationalism. Its slogan is 'don't be dumb, react! Spaniards first'. E-2000 emphasises law and order, tax reduction and anti-immigration policies in its programmatic agenda. In turn, it also uses the slogan 'Spaniards first', calling it 'social patriotism'. Finally, PxC was founded by Josep Anglada, a former follower of the Francoist leader Blas Piñar. It declares itself to be beyond the socioeconomic left-right divide. Just like DN and E-2000, PxC appeals to those citizens that do not feel represented by the established political parties, are against immigrants and chafe against a perceived usurpation of the voice of the people by the institutions of liberal democracy in Spain. Its slogan is 'natives first'.

Figure 1 shows the electoral results of these parties in national elections since the beginning of the 1980s. None of these parties have obtained more than one per cent of the total Spanish vote in any national election since 1980. The aggregated total number of voters for these parties has been growing in recent years-from approximately 20,000 in the 2004 European elections to approximately 120,000 in the $2010 / 11$ regional elections ${ }^{2}$, mainly due to the recent 'successes' of PxC in Catalonia and E-2000 in the Valencian Community. Yet, despite this growth, the numbers are still insignificant in aggregate terms, the more so for each individual party separately.

(About here: figure 1)

At the same time, there is also a traditional extreme right in Spain, represented by myriad Falangist parties, by the openly Francoist party Fuerza Nueva (New Force), founded by Blas Piñar in 
1976 and which experienced relative — though ephemeral—success in 1979, and by the new party Alternativa Española (Spanish Alternative). These parties share a common worldview that is clearly totalitarian. As Casals (2005, p. 130) has noted, the discourse of these parties has 'remained virtually identical to that of its counterpart of the 1930s'. Their ideological links with fascism and Francoism, respectively, make these parties morally distasteful to the great majority of Spanish citizens. Because of their fascist heritage and thus their refusal of the democratic system, they do not fit our definition of the PRR party family. Even more importantly, these parties are irrelevant from an electoral and political point of view as none of them has obtained more than one per cent of the vote in any national election in the last thirty years.

Before moving to the next section, it is relevant to emphasise that we are aware of the fact that there is an open academic debate about the differences between traditional extreme right parties and populist radical right parties in Western Europe (e.g., Ignazi 2003; Rydgren 2007). Suffice it to say here that we follow the approach of Mudde (2007), who argues that the main discrepancy between these two types of rightist parties lies in their approach towards the existing political regime: whereas traditional extreme right parties are openly anti-democratic, populist radical right parties are against certain elements of the liberal democratic regime but not necessarily against democracy per se (see also Rovira Kaltwasser 2014). Seen in this light, for instance, Golden Dawn in Greece and the British National Party in the UK should be categorised as examples of the traditional extreme right and not of the populist radical right. On the fascist heritage of Golden Dawn and the British National Party, see Ellinas (2013) and Goodwin (2014) respectively.

\section{Theory: The Impact of the Cleavage Structure on the Electoral Fortune of the PRR}


In order to find a niche for themselves, PRR parties need to define the classic socioeconomic left-right divide as an obsolete distinction and politicise certain issues that are not being addressed by mainstream political forces. If PRR parties are able to do this in a credible way, they can present themselves as parties beyond traditional ideological differences, representing those voters who are the 'unwanted children' of the silent revolution due to the expansion of postmaterialist values in the affluent societies of Western Europe (Ignazi 1992). In this sense, the success of PRR parties is directly related to their capacity to politicise new points of conflicts that are not necessarily aligned with, but crosscut, the existing cleavage structure of Western European societies. As Hanspeter Kriesi and his collaborators (2008) have pointed out, the emergence of both the PRR and the Greens should be seen as the result of a new political cleavage in Western Europe. Whereas this new political cleavage is based on cultural issues and identity politics (i.e. post-materialist values), the classic socioeconomic left-right cleavage rests on economic disputes and the role of the state regarding socioeconomic inequalities (i.e. materialist values). Otherwise stated, Lipset and Rokkan's famous freezing thesis of the party system in Western Europe is not valid anymore. Due to their ability to stand for and politicise demands that were not taken up by the established political parties, two new party families - the Greens and the PRR—have been able to increase their parliamentary presence across Western Europe and even enter national governments in some countries (Mudde 2013).

However, scholars who are employing the cleavage approach to analyse the electoral fortune of PRR parties in Western Europe have not devoted enough attention to the ways in which the existing cleavage structure of a country can obstruct or facilitate the success of these parties. As the classic sociology of parties has underlined, many societies are characterised not only by the socioeconomic left-right conflict, but also by the co-existence of multiple social cleavages, which end up 
structuring the party system in a complex way as the main issues at stake in the political arena are not self-evident (Boix 2007). In places where different cleavages exist and are relevant to the electorate, Schattenschneider's thesis seems to be more than valid:

[...] political cleavages are extremely likely to be incompatible with each other. [...] The new conflict can become dominant only if the old one is subordinated, or obscured, or forgotten, or loses its capacity to excite the contestants, or becomes irrelevant. Since it is impossible to keep the old and cultivate the new at the same time, people must choose among conflicts. In other words, conflicts compete with each other (Schattschneider 1960, pp. 62-63).

Therefore, there are good reasons to consider the electoral success of the PRR inversely related to the extent to which the political structure is divided by two or more cleavages. In such a scenario, PRR parties need to find a niche that is not owned by any of the established parties and occupy the niche issues with credibility (Meguid 2008). As Simon Bornschier (2010) has postulated, if electorates remain firmly entrenched in older cleavages, PRR parties will find it extremely difficult to establish themselves. The more the existing cleavage structure organises the political space, the more difficult is for a political party to emerge by trying to politicise new subjects, such as the debate on immigration or ecological issues. Voters care about multiple issues and parties are organisations that structure the political landscape by politicising some issues and mobilising certain groups. Thus, the formation of new partisan divides in a country occurs when parties are able to realign the political landscape by incorporating new competitive dimensions, which are salient to the electorate (Kitschelt 2007). Following this observation, it is not far-fetched to suggest that the strength of the cleavage structure of an existing country is significantly connected to the capacity of established political parties to keep these old conflicts alive and socialise new generations into the dominant ideological divisions.

Accordingly, the PRR faces a difficult scenario in countries where the centre-periphery division has been transmitted over generations and thus continues to be a relevant conflict. The 
reason for this lies not only in the entrenchment of the existing cleavage structure, but also in the nativist nature of the PRR. Given that nativism involves the defence of an exclusionary rhetoric focused on cultural traits specific to a particular national community, the PRR ends up alienating voters who might have anti-immigrant attitudes or adhere to the populist set of ideas but identify with another national community (e.g. Catalonia) or consider themselves citizens with dual national identities (e.g. Catalonian and Spanish). As a consequence, the exclusionary appeals of the PRR's nativism seem to be a double-edged sword in countries with an established centre-periphery cleavage: while they can help to give voice to far right voters, they wind up scaring all those who are against the promotion of exclusionary understandings of the nation.

While in this article we do not intend to test empirically the validity of this theoretical argument beyond Spain, it is worth mentioning that in other Western European countries where the centre-periphery cleavage is strong, the strategy of the PRR has consisted in combining nativism with separatism: the defence of the periphery's territorial and cultural interests (i.e. ethnic nationalism) is presented as a battle against not only the state but also, and increasingly, against immigrants that arrive to the peripheral territory and endanger the periphery's cultural homogeneity and economic sustainability. For instance, this is the path followed by the Northern League in Italy and the Flemish Block/Interest in Belgium, as demonstrated by Alonso (2012). Most importantly for our argument, however, is the fact that both the Northern League and the Flemish Block/Interest were born as parties along the centre-periphery cleavage. Only later, as the structure of electoral competition changed and their peripheral agendas were being assumed by mainstream Belgian and Italian parties, thereby threatening their electoral niches, did the Northern League and the Flemish Block/Interest diversify their programmatic appeal to extend to anti-immigration and anti-system issues - issues that, by the way, have not yet been used by another party (Alonso 2012). 
To sum up, in countries divided by a centre-periphery cleavage, PRR parties have difficulty finding a space for themselves, given that nativism is to a certain extent already credibly occupied by established parties (state centralist and peripheral nationalist alike). The Northern League in Italy and the Flemish Block/Interest in Belgium have been the exception rather than the rule: they had well established credibility as peripheral and right-wing parties before starting to play the antiimmigration card (Alonso 2012). As Matthew Goodwin has recently indicated, 'parties that have sprung from diffuse traditions and only later targeted the more sensitive issue of immigration (and increasingly also Islam) have benefitted from a "reputational shield", which has protected against charges of crude racism, extremism and neo-Nazism' (Goodwin 2014, p. 895, italics in original). New PRR parties need to find a way of framing nativism in terms that differentiate them from the nationalism of established parties if they want to succeed. Combining a right-wing ideology with nativism and separatism is one of them, and a successful one too. However, it is not open to all PRR parties, only to those organised in culturally diverse regions of the state.

The recent growth of the UK Independence Party (UKIP) in the UK may seem to contradict our argument about the cleavage structure. After all, the UK is also divided by a strong centre-periphery cleavage and, therefore, according to our argument, we should not see the emergence of a party such as the UKIP. In line with our argument, a PRR party would only achieve success in the UK if it originates from a peripheral party that recycles itself into an anti-immigrant populist party, à la Flemish Block/Northern League. However, this is very unlikely in the UK since the two largest peripheral parties, the Plaid Cymru (PC) and the Scottish National Party (SNP), are left-wing parties along the socioeconomic cleavage, unlike the Flemish Block/Interest and the Northern League, which have been rightist parties since their inception. It is too early to say yet whether the UKIP disproves our argument or not. To begin with, its growth has so far been limited 
to European elections, particularly in the year 2014 when UKIP obtained a bit less than 30 per cent of the vote. In spite of that, there is abundant research demonstrating that European elections are second-order elections (e.g., Carrubba \& Timpone 2005; Franklin \& Hobolt 2011; van der Eijk, Franklin \& Marsh 1996), which partly explains the vote for the UKIP. The growth of the UKIP has to be maintained in national elections, under a much more disproportional electoral system, before we can say that it is more than a flash-party phenomenon resulting from the effects of the economic crisis. Whether the UKIP will have the capacity to achieve initial success in national elections and endure is still an open question, but the increasing Euroscepticism of the British Conservative Party certainly represents a major challenge to the UKIP (Ford, Goodwin \& Cutts 2012).

\section{Empirical Analysis: Demand and Supply-Side Factors}

The most common way to study the emergence and evolution of PRR parties is to analyse the interaction between demand-side and supply-side factors (e.g., Eatwell 2003; Mudde 2007; Norris 2005; Rydgren 2007; van der Brug, Fennema \& Tillie 2005). By taking into account both factors, the electoral fortune of the parties in question is analysed within a framework that invites us to think about democratic politics as a marketplace. While the demand-side factors allude to a combination of occasional and structural changes that influence the preferences of the voters, the supply-side factors refer to a set of internal and external conditions that determine the electoral performance of political parties. Building on this line of reasoning, the following two sections seek to demonstrate that 1) the electoral potential of the PRR in Spain was, at least during the 1990s and 2000s, as great as in other Western European countries, and 2) supply-side factors - in particular the 
cleavage structure of the country-indeed explain why this party family has not taken roots in Spain yet.

\section{Demand-side Factors}

When it comes to thinking about structural changes that favour the emergence of the PRR, the most obvious is an increase in ethnic heterogeneity due to rising immigration. As a consequence of the arrival of foreigners from different parts of the world, most Western European countries have seen the emergence since the mid-1980s of new grievances mobilised by new parties and political actors (Ignazi 1992). While it is true that in Spain these grievances were probably neither present nor salient during the 1980s, the social structure of Spanish society started to change because of immigration at the end of the 1990 s at the latest. According to the data of the Ministry of the Interior, while at the beginning of the 1990s no more than two per cent of the population were foreign-born legal residents, this number had risen to twelve per cent in $2013^{3}$. At the same time, it is estimated that illegal immigration has increased in the last twenty years. Although it is difficult to give exact estimates, a comparison of the data from the Ministry of the Interior on the Padrón Municipal (register of residents), the best available method for estimating this ${ }^{4}$, tells us that in 2000 there were a total of 28,159 foreign-born residents without legal residency in Spain; by the end of 2010 this figure had grown to 824,879 .

The rising number of immigrants has not gone unnoticed among the general public. For instance, the comparison of the 1996 and 2009 Barometer of the Centro de Investigaciones Sociologicas (Centre of Sociological Research, CIS) on attitudes towards immigration (surveys 2214 \& 2817), coinciding with the boom of foreigners coming into the country, both legally and illegally, reveals 
that this was a period of tremendous growth of anti-immigrant attitudes in Spain (see figure 2). At the same time, the immigration issue obtained increasing media and public attention during the 2000s. It reached its peak in October 2006, when 59 per cent of Spaniards saw immigration as Spain's main problem (CIS series), coinciding with a period of high TV news coverage by the main national television broadcasters. Research undertaken by Lorite García (2006-2009) and Igartua, Muñiz \& Otero (2006) reveals that television news not only increased the coverage of broadcasts related to immigration, but also tended to adopt a negative tone, framing the arrival of immigrants as an 'invasion', linking illegal immigration with unlawful acts, and continuously discussed the necessity of undertaking legislative changes to control immigration.

(About here: figure 2)

There is abundant empirical evidence demonstrating that during this time Spanish citizens were no more-nor necessarily less - tolerant than their Western European brethren. According to the European Social Survey (ESS) in 2006, the year in which immigration figured as the main problem in Spain for a majority of Spaniards (59 per cent), when asked whether immigrants from other races or ethnic groups should be allowed to enter the country, 13 per cent of Spaniards declared that many should be allowed and 15 per cent answered that none should be. The mean distribution of responses for the 23 European countries in the dataset was 13 per cent and 15 per cent, respectively. Spain's values in 2006 were exactly at the European mean.

Nevertheless, the saliency of immigration started to fade away with the outbreak of the economic crisis in 2008. Although legal immigration continued to grow, the number of illegal immigrants decreased between 2010 and 2013 from 824,879 to 42,267 , probably as a result of the 
Great Recession. In 2011 the number of Spaniards who thought that immigration was the main problem in Spain had already fallen below 10 per cent (a drop of nearly forty points since 2006!) and in May 2013 this figure had been reduced to a mere 1.5 per cent, while the number of Spaniards who indicated that unemployment was the country's main problem was as high as 82 per cent. In $2012^{6}$, when illegal immigration had started to drop and only 5 per cent of Spaniards identified immigration as the main problem in Spain according to the CIS series, attitudes towards immigration had moved in a more positive direction in comparison to 2006, although the difference with the mean European values was still not large. 21 per cent of Spaniards responded that many immigrants from other races or ethnic groups should be allowed in the country, against the European mean of 14 per cent; meanwhile, 11 per cent of Spaniards declared that none should be allowed, against a European mean of 15 per cent. In summary, Spaniards' anti-immigration sentiments were at their peak during the period of economic boom (i.e. the 2000s), a time when Spaniards' anti-immigration attitudes were indistinguishable from other European peoples. With the economic crisis, immigration was no longer considered a major problem and attitudes towards immigration softened.

A second tenet of the PRR is the populist ideology, which has not been absent in Spain. During the period in which immigration became increasingly salient in a negative way (i.e. the 2000s), Spaniards also showed increasing populist and anti-establishment sensibilities, which were exacerbated by the outbreak of the Great Recession. The populist discourse is characterised by the claim that 'the establishment' does not respect popular sovereignty, and the time has come to take power away from political parties and give it back to 'the people' (Mudde \& Rovira Kaltwasser 2013b). The level of trust in democratic institutions (political parties, parliaments and governments) in Spain plummeted in the last two decades, particularly since the outbreak of the Great Recession (see figure 3). Satisfaction with democracy decreased correspondingly. 
(About here: Figures 3 and 4)

In comparative terms, this negative development was quite pronounced. Whereas in 2001 Spaniards (32 per cent) were less unsatisfied with democracy than Germans (36 per cent), French (38 per cent), Greeks (51 per cent), Portuguese (56 per cent) and Italians (59 per cent) ${ }^{7}$, nine years later Spain had the fourth highest number of citizens unsatisfied with democracy, only surpassed by Greece, Portugal and Italy (in that order) ${ }^{8}$. A mere 36 per cent of Spaniards were satisfied or fairly satisfied with democracy in May 2012 (see figure 3). This may well be just a short-term phenomenon driven by discontent with economic austerity and lack of performance of democratic institutions but, nevertheless, it represents a window of opportunity for parties that want to exploit these sentiments (Feenstra \& Keane 2014).

Finally, the third element of the core ideology of the PRR is authoritarianism. The latter has less to do with open support for an autocratic regime and has more to do with a belief in a strictly ordered society and is expressed in a preference for 'law and order' issues. Defined this way, authoritarianism has found considerable support in the Spanish population since the 1980s. According to a 2009 CIS survey $(2799)^{9}$, if the government had to choose between fighting against crime efficiently and protecting individual rights and liberties, 43 per cent of Spaniards would fall on the law-and-order side of the trade-off. This is consistent with another CIS survey conducted in 2008 (2760), in which 39 per cent of Spaniards declared that the main priority of any government should be to keep order and peace. Questioned about what things have gotten worse since the Francoist dictatorship, 62 per cent of Spaniards agreed that insecurity and crime are among them; 81 per cent mentioned the problems associated with drug trafficking and consumption and another 83 
per cent selected terrorism. Moreover, 43 per cent of Spaniards believe that people in Spain were less respectful of authority than during Francoism (CIS 2760).

From a comparative perspective, Spaniards' attitudes are not significantly more proauthoritarian or more pro-libertarian than those in other European countries, as previous research has demonstrated (Bakker \& Edwards 2010; Knutsen 2012). If we look for example at the questions from the 2012 European Social Survey dealing with authoritarian attitudes, such as 'people should follow rules at all times, even when no-one is watching', 'the state [should] be strong so it can defend its citizens' or that it is important 'to get respect' so that people follow orders'10, Spain's mean values are at the median value of the 23 countries in the dataset ${ }^{11}$.

Supply-side Factors

Having considered the demand-side, it is time to turn our attention to the other side of the coin. As David Art has pointed out, '[o]nce we shift our perspective and assume that [populist] radical right parties should win a sizeable share of the vote in Western European states, it is their failure to do so that becomes the interesting question' (Art 2011, p. 15, italics in original). To solve this puzzle, an increasing number of scholars are of the opinion that the key lies in studying supplyside factors (e.g. Art 2011; Mudde 2007; Norris 2005; Rydgren 2007; van der Brug, Fennema \& Tillie 2005). While we agree with this argument, we suggest in this paper one supply-side factor that has received almost no attention in the scholarly debate: the ways in which the structure of cleavages in the country obstructs the rise of PRR parties. This factor, in conjunction with the electoral system and the ability of the Spanish mainstream right-wing party to attract far right voters, provides us a compelling account of the electoral irrelevance of the PRR in Spain. Each of these three supply-side 
factors - the electoral system, the role of the mainstream political parties and the cleavage structure-will be analysed separately in the following pages.

The first element that is important to consider is the electoral system, because it is usually mentioned as one of the main supply-side factors that either facilitates or hinders the success of PRR parties. According to Norris (2005), for example, the less proportional the electoral system, the less likely the success of new parties. Spain has a proportional electoral system but with highly disproportional effects due to the combination of a large number of districts (i.e. 52) of very diverse size (from 2 to 33 electoral districts apiece) and the D'Hondt formula. According to the LoosemoreHanby index, Spain is at times even more disproportional than the UK. ${ }^{12}$ This combination benefits large parties and geographical concentration. Parties with homogeneous and small base throughout Spain are the most damaged by this electoral system.

We should be careful not to exaggerate the effect of the electoral system. As some scholars have demonstrated, highly disproportional systems are not necessarily an obstacle to the rise of PRR parties (Arzheimer \& Carter 2006; van der Brug, Fennema \& Tillie 2005). In Spain, the problem is not the electoral system per se, but its combination with the high level of fragmentation of the PRR party family. If it were just the electoral system, we would have seen PRR parties doing better in European elections. However, in European elections, with the most proportional design of all electoral arenas in Spain, the PRR parties have not done much better than in national elections. No PRR party has ever obtained more than 0.13 per cent of the vote in European elections, but they probably would have done better if they had combined forces in a single candidacy. Further proof that the electoral system is not an insurmountable obstacle to the rise of PRR parties is the recent consolidation of a new party in Spain, Unión, Progreso y Democracia (Union, Progress and Democracy, UPyD), founded in 2007, which has made it to the national parliament in 2008 and 2011. The 
success of UPyD shows that although difficult, breakthrough is not impossible, but the new party needs to find its niche, both in ideological and geographical terms.

The second supply-side factor that it is worth considering is the electoral strategies of competition of mainstream political parties. Previous research on the electoral fortune of PRR parties in Western Europe (e.g., Bornschier 2012, Ellinas 2010, Ignazi 2003, Meguid 2008) has shown that if mainstream parties are able to include to some extent in their agendas the issues that these new parties try to politicise, the mobilisation space for political newcomers is limited. Thus, patterns of party competition are relevant for understanding the electoral fate of the PRR. By anticipating and incorporating some of the demands put forward by the PRR, established political parties can hinder their emergence and/or their growth.

This is precisely what occurred in Spain until the Great Recession. To understand this, it is important to take into account the historical roots of the Partido Popular (People's Party, PP) and its evolution over time. In fact, the PP has its origins in Alianza Popular (People's Alliance), a rightist party that was populated by the political elites of the authoritarian regime and led by Manual Fraga, an erstwhile minister under Franco. The 1980s was a period of deep crisis for Alianza Popular, because the party experienced several internal fights over the moderation of its programmatic agenda and expansion of its electoral appeal beyond its traditional right-wing core constituency. At the beginning of 1989 the party changed its name to Partido Popular and only then was it able to leave the trenches, particularly after José María Aznar became chairman of the party and led the PP to its first electoral victory at a general election in 1996.

Interestingly, the ideological moderation of the PP did not leave the far right voters orphan. The relationship between left-right ideology and voting behaviour is shown in figure 5, with data from CIS post-electoral surveys between 1986 (the year when the left-right scale changed from a 
seven point scale to a ten point scale) and 2011. The values of the 1-10 left-right scale have been grouped into six categories: extreme left (1-2), left (3-4), centre-left (5), centre-right (6), right (7-8), extreme right (9-10). As the graph demonstrates, the percentage of people self-placed on the centreright, the right or the extreme right that vote for the PP increases with time. In the 2011 national elections, between 80 and 83 per cent of the right and extreme right voters voted for the PP, and in consequence, it is not far-fetched to suggest that in the case of Spain the mainstream right has preempted the rise of the PRR ${ }^{13}$.

(About here: figure 5)

The most relevant and least analysed supply-side factor when it comes to explaining the electoral irrelevance of the PRR in Spain is the ways in which the cleavage structure is obstructing the take-off of PRR parties in the country. This cleavage structure is characterised by the presence of two main cross-cutting cleavages: socioeconomic left-right and centre-periphery. While the former alludes mainly to the conflict about the role of the state in economic development, the latter refers essentially to disputes related to political control over certain territorial units demanding more autonomy on the basis of differentiated claims to nationhood. As such, Spain is a country marked not only by debates about the state vs. the market, but also by the difficult coexistence of state and peripheral nationalisms, with conflicting claims to nationhood reflected in citizens' diverse national identities, that include an exclusive Spanish identity, an exclusive national peripheral identity (e.g. Basque or Catalan), and a dual identity (e.g. as Spanish as Basque). There is on-going tension and negotiation between a multiplicity of national and peripheral identities (e.g., the Basque country, 
Catalonia, Galicia, the Canary Islands, etc.) vis-à-vis a centralist tradition based on a Castilian ethnic core interested in defending the indissoluble unity of the Spanish nation.

In order to reveal the relevance of the centre-periphery cleavage vis-à-vis the classic socioeconomic left-right conflict and the debate about immigration, we can draw on the data of the Manifesto Project (Volkens et al. 2013), which is based on quantitative content analysis of parties' electoral programs. The Manifesto data allow us to look at the relevance of policy issues in party manifestos. Given that our interest is in socioeconomic, centre-periphery and immigration issues, we will concentrate the analysis on the following sets of opposing issues:

a. Market liberalism versus market intervention (issue categories: per401 + per407 + per414 + per403 + per404 + per412)

b. Welfare state pro and con (issue categories: per506 + per504 + per507 + per505)

c. Centre versus periphery (issue categories: per301 + per302 + per601 + per602)

d. Immigration pro and con (issue categories: per607 + per705 + per608)

Table 2 shows the mean percentage of sentences in Spanish party manifestos dedicated to issues belonging to the socioeconomic left-right, the centre-periphery and the immigration vs. antiimmigration dimensions of electoral competition between 1979 and 2011. Socio-economic and centre-periphery issues have always been more important for Spanish parties than immigration issues. The centre-periphery dimension has even surpassed the welfare state dimension and the market-versus-state dimension in all elections since 1996, the year when the PP was elected to office for the first time, under the premiership of José María Aznar. Unsurprisingly, the years of the PP in office (between 1996 and 2004) were a period in which welfare state issues were at a relative low point with respect to centre-periphery and immigration issues, the latter being at their highest 
relevance in party manifestos. There is no doubt that the PP used nationalism and immigration as strong points in its strategy of electoral competition.

\section{(About here: table 2)}

Thus, the central argument of our paper is that Spain's cleavage structure has made the life of the PRR particularly difficult. As we mentioned before, nativism —or ethnic nationalism, to use a more 'European' term-is, together with authoritarianism and populism, the core of the PRR parties' programmatic profile. In Spain, this programmatic profile has left little space for a newcomer since most of it (with the exception of populism) is part and parcel of the centreperiphery cleavage and this, in turn, has been well represented and articulated by established national (e.g. PP) and regional parties (e.g., PNV, EH-Bildu, CiU, ERC, BNG, etc.), large and small alike. In fact, the centre-periphery conflict has been at the heart of Spanish politics for more than a century. During the transition to democracy the so-called 'national question' was a crucial issue and a fundamental challenge to the success of the process of democratisation. Spanish politicians at the constituent assembly of 1977-1979 agreed that the new democratic regime should avoid the extreme centralisation of the state and the 'monopolisation of patriotism' (Muñoz 2009, p. 620) of the Franco regime. Extreme centralisation and dictatorship were linked to such an extent that the success of democracy, it was believed, required the establishment of a decentralised state and the recognition of the national minorities within it, to break with the past (Aja 2003; Alonso 2012; Muñoz 2009). Moreover, the high level of mobilisation of the Catalan and Basque minority nationalists in favour of re-establishing the regional autonomies that they had enjoyed at the end of the Second Republic was a further indication that the design of the state would have to somehow 
incorporate the demands for self-government coming from the culturally and territorially distinct peripheries (Aja 2003; Alonso 2012). As part of this process, 'the definition of the Spanish nation had to evolve from the traditionalist national-Catholicism of the regime towards a new, democratic and inclusive conception of nationhood' (Muñoz 2009, p. 620).

Given that Francoist nationalism had at its centre the identification of the nation with Catholicism, traditionalism and Castilian ethnicity, it was clearly biased towards the most right-wing segments of the Spanish society. Despite efforts to the contrary since then, Catholicism and the right are still linked to an unitary conception of the Spanish nation, in contrast to the secularised left, that defends a more pluralist multinational concept (De la Calle et al. 2013). This is well reflected in Figure 6, with data from the 2009 CIS survey (2667). The more to the right respondents placed themselves, the more likely they were to link national identity with Catholicism, the Castilian language, patriotic pride and a unitary centralised state. We have already shown that the PP has been hegemonic among this group of voters at least until 2011 (see figure 5). In fact, the PP is by history and ideology a Spanish centralist party that believes that the nation in Spain is one and indivisible and that Catholicism and the Castilian language are among the essential features of the Spanish nation (Field \& Botti 2013).

(About here: figure 6)

In consequence, the problem is that the battle between political parties in Spain is as much about nationalism, the territorial question and the roles of religion and traditional values as it is about attitudes towards socioeconomic equality, the role of the state in the economy and immigration. Therefore, in the case of Spain the PRR has had to deal with a very difficult political 
space, because two of its main tenets-nativism expressed in the debate about the nation and authoritarianism expressed in law and order issues_-have been part and parcel of the two historically established cleavages, the centre-periphery and the socioeconomic left-right. A strong emphasis on nativism is certainly not the way ahead for the Spanish PRR, since this would mean choosing between one of the several contending definitions of the nations that coexist in Spain (as we said before, this would not apply to an already established peripheral party that decides to move into an antiimmigrant direction, since this party would already have established its credibility as a peripheral nativist party). The risk of doing this is twofold. On the one hand, the state nationalism and the peripheral nationalism camps are already well represented by the existing parties, and the PRR would need to convince voters that their position is really different. On the other hand, choosing one camp would imply alienating one part of their potential electorate.

An emphasis on immigration would most likely have been profitable, given the increase of anti-immigrant attitudes among Spaniards during the 2000s. The problem with the issue of immigration is that it needs to be framed in a discourse of 'us versus them' and this brings PRR parties back to the definition of 'us'. A way out of this dilemma is to concentrate on defining 'them' while leaving the definition of 'us' intentionally vague, as $\mathrm{PxC}$ has been doing in Catalonia and which may explain its success in comparison to the other PRR parties in Spain, even if it is still quite irrelevant when compared with other PRR successes across Europe. Welfare chauvinism is of help here, given that to defend its propositions it is enough to define the outsiders, i.e. those that should be pushed out—or, if already out, kept out—of the system of welfare state protection. However, welfare chauvinism was, to some extent, already captured by the PP and therefore the PRR could not rely exclusively on this to gain a foothold. Whether the Great Recession is opening a window of opportunity for the PRR in Spain is still an open question, which we address at the end of our paper. 


\section{Conclusion}

The PRR is a real source of fascination for pundits and academics alike. As Tim Bale (2012) has recently indicated, the interest in the PRR goes well beyond the ivory tower of academia, because it leads to a debate about not only how European societies should deal with immigration, but also how well democracy is functioning across Europe. However, existing research has put too much emphasis on those Western European countries where the PRR has been gaining influence. This means that scholars have dealt only cursorily with those Western European countries where the PRR is almost absent and irrelevant. In this regard, Spain represents a paradigmatic example, because it has experienced increasing immigration in the last two decades and anti-immigrant attitudes are widespread in Spanish society. In spite of that, no PRR party has been able to obtain more than one per cent of the vote in any national, regional or European election.

In this paper we have tried to explain this puzzling situation by analysing both demand-side and supply-side factors. In consonance with the work of other scholars (e.g., Art 2011, Mudde 2007), we have shown that the rise of the PRR is related less to the former and more to the latter factors. In other words, given that several indicators show that in Spain there is fertile soil for the PRR, its electoral and political irrelevance has to do first and foremost with supply-side factors. In more concrete terms, we found that the main impediments that the PRR has faced since the 1990s in Spain are the following three (listed in order of importance): first, a cleavage structure characterised by an entrenched conflict between peripheral and state nationalisms, so that PRR parties, as newcomers, have had serious problems playing the nativist card; second, a mainstream right-wing party (PP) which deliberately or not has been able to obtain the support of far right 
voters and thus has left little space for the establishment of the PRR; third, an electoral system that is highly disproportional, and hence obstructs the rise of new parties regardless of their electoral agenda.

It is worth indicating the connection between these three impediments. The Spanish cleavage structure was well entrenched during the period analysed largely because of the capacity of national and regional parties to represent the ideas and interests of the electorate. Spain has a long tradition of conflict between peripheral and state nationalisms, which is kept alive by different parties. These political organisations have evolved over time not only in their conception of the centre-periphery and socioeconomic left-right debate, but also in their ability to include other topics that are also relevant for sections of the electorate. The more the mainstream conservative party has been able to give voice to extreme right voters who are in favour of law and order, Castilian centralism and tougher control on immigration, the less space has been left for the emergence and consolidation of PRR parties. In addition, the existing electoral system hinders the entrance of new parties and this is particularly problematic for the PRR in Spain as the party family is highly fragmented and divided in several organisations which maintain a strong rivalry.

At this stage, the obvious question is whether the electoral irrelevance of the Spanish PRR is going to last or whether Spain might experience a similar political development to that witnessed in other Western European countries such as Austria, France, the Netherlands and Switzerland, i.e. the emergence and electoral consolidation of the PRR. While in this concluding section we cannot offer a detailed answer to this question, we would like to finish this work by providing some tentative ideas on this subject. Demand- and supply-side factors take us in opposite directions. The demandside factors in favour of the PRR have become much less salient since the Great Recession. From 2010 onwards, immigration moved down the list of salient issues and there is growing public anxiety 
over the economy and unemployment. This does not fare well for an electoral take-off of the PRR family, particularly since internal fragmentation remains unchanged. However, the supply-side factors that have played against the PRR are now changing.

The Great Recession might well have a long-lasting effect in the Spanish party system, since the two mainstream political parties-PP and Partido Socialista Obrero Español, Spanish Socialist Workers' Party (PSOE)-have advocated and enacted painful economic reforms that are having a devastating impact on Spanish society. Not only has unemployment reached terrible levels, but poverty and inequality are increasing at a fast pace. Moreover, most of these reforms have been promoted by the current conservative government of the PP, and in consequence, the PRR has an exceptional opportunity to present itself as the real defender of the ideas and interests of 'the people', particularly when it comes to playing the welfare chauvinism card and attacking foreign powers for their imposition of drastic austerity programs. Nevertheless, as we have argued in this paper, waving the nativist flag seems to be counterproductive for the PRR, because this strategy necessary involves answering the question of who 'we, the Spanish people' are. Thus, the way ahead probably has less to do with defining 'us' and more to do with delineating 'them', namely, those actors and institutions that are acting against the will of the people.

Accordingly, at least in the case of Spain the Great Recession is making not PRR parties as such more appealing, but rather one specific ideological component of these parties, namely populism. By comparison, consider Greece, another Southern European country which has been forced to enact painful austerity reforms opposed by the majority of the population. In our opinion, the most impressive change in the Greek political system is not that Golden Dawn-a party that due to its fascist heritage (Ellinas 2013) we categorise as an example of the traditional extreme right and not of the populist radical right-obtained approximately 7 per cent of the vote in the 2012 national 
elections. Much more striking is the fact that the populist ideology has been employed with great success in Greece by a leftist political party: SYRIZA. A previously unknown Greek political formation, SYRIZA managed to climb to 26.9 per cent of the vote in the 2012 national elections by developing a leftist populist ideology (Stavrakakis \& Katsambekis 2014). This new type of leftist populism is characterised by a radical critique of the austerity measures enacted by the established political parties, and promoted by the Northern European countries and the International Monetary Fund in conjunction, as well as a demand for changes in the taxation system, the way in which the financial sector should be controlled and the capacity of 'the people' to enact the popular will.

It is worth noting that this kind of leftist populism does not rely on the new political cleavage centred on identity politics, but rather on the classic conflict related to material redistribution. In consequence, leftist populism can develop an inclusionary rhetoric by defining 'the pure people' as all those who are excluded and discriminated against, and framing 'the corrupt elite' as an oligarchy which, due to its alliance with foreign powers (e.g. the European Union and transnational business elites), is not qualified to represent and enact the popular will (Mudde \& Rovira Kaltwasser 2013a; Rovira Kaltwasser 2014). Given that leftist populist forces are not necessarily interested in employing nativist language, they could easily avoid taking sides in the Spanish centre-periphery struggle, allowing them to develop an electoral platform that can attract voters with different and even antagonistic ideas about the nation. Thus, it should not be a big surprise that in the last European elections Podemos - a leftist party with a populist discourseobtained approximately eight per cent of the vote in Spain. Whether Podemos will be able to achieve initial success in national elections and endure is still an open question, but the odds are in their favour. 
In summary, although we do not have a crystal ball to predict the future, we see many signs that indicate that there is a breeding ground for the rise of leaders who can make use of the populist ideology to advance a radical left rather than a radical right agenda in contemporary Spain. In this sense, it is worth noting that leftist populist parties exist in both Eastern and Western Europe (March 2011), and that certain voices within the recent movement of the indignados did have clear left-wing populist tendencies. To the basic question 'is there a chance that the PRR gains influence in Spain in the coming years?' our general answer is therefore 'yes'-but with a twist. Given that in contemporary Spain the electoral potential of the PRR is related more to populism than to nativism and the Great Recession is bringing to the fore material instead of post-material politics, it would not be surprising if the country experiences the rise and consolidation of a leftist populist party at the national level in the near future.

\section{References}

Aja, E. (2003) El Estado autonómico: Federalismo y hechos diferenciales, Alianza, Madrid.

Alonso, S. (2012) Challenging the State: Devolution and the Battle for Partisan Identity. A Comparison of Belgium, Italy, Spain, and the United Kingdom, Oxford University Press, Oxford.

Art, D. (2011) Inside the Radical Right. The Development of Anti-Immigrant Parties in Western Europe, Cambridge University Press, Cambridge.

Arzheimer, K. \& Carter, E. (2006) 'Political opportunity structures and right-wing extremist party success', European Journal of Political Research, vol. 45, no. 3, pp. 419-443.

Bakker, R. \& Edwards, E. (2010) 'The dimensionality of party politics in Europe', paper presented at the European Consortium for Political Research's Fifth Pan-European Conference on EU 
Politics, Porto, 23-26 June .

Bale, T. (2012) 'Supplying the insatiable demand: Europe's populist radical right', Government \& Opposition, vol. 47, no. 2, pp. 256-274.

Boix, C. (2007) 'The Emergence of Parties and Party Systems', in The Oxford Handbook of Comparative Politics, eds C. Boix \& S. Stokes, Oxford University Press, Oxford, pp. 499-521.

Bornschier, S. (2010) Cleavage Politics and the Populist Right. The New Cultural Conflict in Western Europe, Temple University Press, Philadelphia.

- (2012) 'Why a right-wing populist party emerged in France but not in Germany: cleavages and actors in the formation of a new cultural divide', European Political Science Review, vol. 4, no. 1, pp. 121-145.

Carrubba, C. \& Timpone, R. (2005) 'Explaining vote switching across first- and second-order elections: evidence from Europe', Comparative Political Studies, vol. 38, no. 3, pp. 260-281.

Casals, X. (2005) 'Spain: the long journey from neo-Francoism to national populism (1975-2005)', in Political Survival on the Extreme Right. European Movements between the Inherited Past and the Need to Adapt to the Future, ed. X. Casals, Institut de Ciències Polítiques i Socials, Barcelona, pp. 127-145.

De la Calle, L., Roussias, N. \& Sánchez-Cuenca, I. (2013) 'Ideología e identificación partidista', in Elecciones y votantes, ed J. R. Montero, Alianza, Madrid.

Eatwell, R. (2003) 'Ten theories of the extreme right', in Right-Wing Extremism in the Twenty-First Century, eds P. Merkl \& L. Weinberg, Frank Cass, London, pp. 45-70.

Ellinas, A.A. (2010) The Media and the Far Right in Western Europe: Playing the Nationalist Card, Cambridge University Press, New York.

- (2013) 'The rise of Golden Dawn: the new face of the far right in Greece', South European Society and Politics, vol. 18, no. 4, pp. 543-565. 
Ford, R., Goodwin, M. \& Cutts, D. (2012) 'Strategic Eurosceptics and polite xenophobes: support for the United Kingdom Independence Party (UKIP) in the 2009 European Parliament elections', European Journal of Political Research, vol. 51, no. 2, pp. 204-234.

Franklin, M. \& Hobolt, S. (2011) 'The legacy of lethargy: how elections to the European Parliament depress turnout', Electoral Studies, vol. 30, no. 1, pp. 67-76.

Goodwin, M. (2014) 'Forever a false dawn? Explaining the electoral collapse of the British National Party (BNP)', Parliamentary Affairs, vol. 67, no. 4, pp 887-906.

Feenstra, R. \& Keane, J. (2014) 'Politics in Spain: A Case of Monitory Democracy', Voluntas, vol. 25, pp 1262-1280. DOI 10.1007/s11266-014-9461-2.

Field, B., \& Botti, A., (eds.) (2013) Politics and Society in Contemporary Spain: From Zapatero to Rajoy, Palgrave Macmillan, New York.

Igartua, J.J., Muñiz, C. \& Otero, J.A. (2006) 'El tratamiento informativo de la inmigración en la prensa y la televisión española. Una aproximación empírica desde la teoría del Framing', Global Media Journal, vol. 3, no. 5, pp. 1-15.

Ignazi, P. (1992) 'The silent counter-revolution. Hypotheses on the emergence of extreme-right wing parties in Europe', European Journal of Political Research, vol. 22, no. 1, pp. 3-34.

- (2003) Extreme Right Parties in Western Europe, Oxford University Press, Oxford .

Kitschelt, H. (2007) 'Party systems', in The Oxford Handbook of Comparative Politics, eds C. Boix \& S. Stokes, Oxford University Press, Oxford, pp. 522-554.

Knutsen, O. (2012) 'Conflict dimension in the West European party systems: A comparative study based on European Values Study 2008, paper presented at the XXII World Congress of Political Science, Madrid, 8-12 July.

Kriesi, H. et al. (2008) West European Politics in the Age of Globalization, Cambridge University Press, 
Cambridge.

Lorite García, N. (2006-2009) Tratamiento Informativo de la Inmigración en España. Años 2006 a 2009, MIGRACOM, Observatorio y Grupo de Investigación de Migración y Comunicación, Universidad Autónoma de Barcelona, Barcelona.

March, L. (2011) Radical Left Parties in Europe, Routledge, London.

Meguid, B. (2008) Party Competition Between Unequals, Cambridge University Press, Cambridge.

Mudde, C. (2004) 'The populist zeitgeist', Government \& Opposition, vol. 39, no. 4, pp. 541-563.

- (2007) Populist Radical Right Parties in Europe, Cambridge University Press, Cambridge.

- (2013) 'Three decades of populist radical right parties in Western Europe: so what?', European Journal of Political Research, vol. 52, no. 1, pp. 1-19.

Mudde, C. \& Rovira Kaltwasser, C. (2013a) 'Exclusionary vs. Inclusionary Populism: Comparing Contemporary Europe and Latin America', Government \& Opposition, vol. 48, no. 2, pp. 147-174.

- (2013b) 'Populism', in The Oxford Handbook of Political Ideologies, eds M. Freeden, M. Stears \& L. T. Sergeant, Oxford University Press, Oxford, pp. 493-512.

Muñoz, J. (2009) 'From National-Catholicism to Democratic Patriotism? Democratization and reconstruction of national pride: the case of Spain (1981-2000)', Ethnic and Racial Studies, vol. 32, no. 4 , pp. 616-639.

Norris, P. (2005) Radical Right: Voters and Parties in the Electoral Market, Cambridge University Press, Cambridge.

Rovira Kaltwasser, C. (2014) 'The Responses of Populism to Dahl's Democratic Dilemmas', Political Studies, vol. 62, no. 3, pp. 470-487.

Rydgren, J. (2007) 'The sociology of the radical right', Annual Review of Sociology, vol. 33, pp. 241-262.

Schattschneider, E.E. (1960) The Semisovereign People: A Realist's View of Democracy in America, Hold, 


\section{Rinehart and Winston, New York.}

Stavrakakis, Y. \& Katsambekis, G. (2014) 'Left-wing populism in the European periphery: the case of SYRIZA', Journal of Political Ideologies, vol. 19, no. 2, pp. 119-142.

van der Brug, W., Fennema, M. \& Tillie, J. (2005) 'Why some anti-immigrant parties fail and others succeed: a two-step model of aggregate electoral support', Comparative Political Studies, vol. 38, no. 5, pp. 537-573.

van de Eijk, C., Franklin, M. \& Marsh, M. (1996) 'What voters teach us about Europe-wide elections: what Europe-wide elections teach us about voters', Electoral Studies, vol. 15, no. 2, pp. 149-166.

Volkens, A. et al. (2013) The Manifesto Data Collection. The Manifesto Project (MRG/CMP/MARPOR) Version 2013b, Wissenschaftszentrum Berlin für Sozialforschung (WZB), Berlin. 
Table 1 Results of PRR Parties in National Elections in Western Europe between 1980 and 2014

\begin{tabular}{|c|c|c|c|c|c|c|c|c|c|c|c|c|}
\hline \multirow{2}{*}{$\begin{array}{l}\text { COUNTRY } \\
\text { Austria }\end{array}$} & \multirow[t]{2}{*}{ PARTY } & \multicolumn{11}{|c|}{ YEAR } \\
\hline & & & 1983 & 1986 & 1990 & 1994 & 1995 & 1999 & 2002 & 2006 & 2008 & 2013 \\
\hline & $\begin{array}{l}\text { Freedom } \\
\text { Party of } \\
\text { Austria } \\
\text { (FPÖ) } \\
\text { Alliance for } \\
\text { the Future } \\
\text { of Austria } \\
\text { (BZÖ) }\end{array}$ & & 5 & 9.7 & 16.6 & 22.5 & 21.9 & 26.9 & 10 & 11.4 & 17.5 & 20.5 \\
\hline \multirow[t]{2}{*}{ Belgium } & & & 1981 & 1985 & 1987 & 1991 & 1995 & 1999 & 2003 & 2007 & 2010 & 2014 \\
\hline & $\begin{array}{l}\text { Vlaams } \\
\text { Blok/Belang } \\
(\mathrm{VB}) \\
\text { New } \\
\text { Flemish } \\
\text { Alliance (N- } \\
\text { VA) }\end{array}$ & & 1.1 & 1.4 & 1.9 & 6.6 & 7.8 & 9.9 & 11.7 & 18.5 & 17.4 & 20.7 \\
\hline \multirow[t]{2}{*}{ Denmark } & & 1981 & 1984 & 1987 & 1988 & 1990 & 1994 & 1998 & 2001 & 2005 & 2007 & 2011 \\
\hline & $\begin{array}{l}\text { Danish } \\
\text { People's } \\
\text { Party (DFP) } \\
\text { Progress } \\
\text { Party (FP) }\end{array}$ & 8.9 & 3.6 & 4.8 & 8.9 & 6.4 & 6.4 & 2.4 & $\begin{array}{l}12 \\
0.6\end{array}$ & 13.2 & 13.9 & 12.3 \\
\hline \multirow[t]{2}{*}{ Finland } & & & & & & & & 1995 & 1999 & 2003 & 2007 & 2011 \\
\hline & $\begin{array}{l}\text { Finns Party } \\
\text { (PS) }\end{array}$ & & & & & & & 1.3 & 1 & 1.6 & 4.1 & 19.1 \\
\hline \multirow[t]{2}{*}{ France } & & & & & & 1986 & 1988 & 1993 & 1997 & 2002 & 2007 & 2012 \\
\hline & $\begin{array}{l}\text { National } \\
\text { Front (FN) }\end{array}$ & & & & & 9.8 & 9.8 & 12.7 & 14.9 & 11.3 & 4.9 & 13.6 \\
\hline \multirow[t]{2}{*}{ Germany } & & & & & & 1990 & 1994 & 1998 & 2002 & 2005 & 2009 & 2013 \\
\hline & $\begin{array}{l}\text { The } \\
\text { Republicnas } \\
\text { (REP) }\end{array}$ & & & & & 2.1 & 1.9 & 1.8 & 0.6 & 0.6 & 0.4 & 0.2 \\
\hline \multirow[t]{2}{*}{ Greece } & & & & & & & & & 2004 & 2007 & 2009 & 2012 \\
\hline & $\begin{array}{l}\text { Popular } \\
\text { Orthodox } \\
\text { Party } \\
\text { (LAOS) }\end{array}$ & & & & & & & & 2.2 & 3.8 & 5.6 & 2.9 \\
\hline Italy & & & & & 1992 & 1994 & 1996 & 2001 & 2004 & 2006 & 2008 & 2013 \\
\hline & Northern & & & & 8.6 & 8.6 & 10.1 & 3.9 & 5 & 4.6 & 8.3 & 4.1 \\
\hline
\end{tabular}


League (LN)

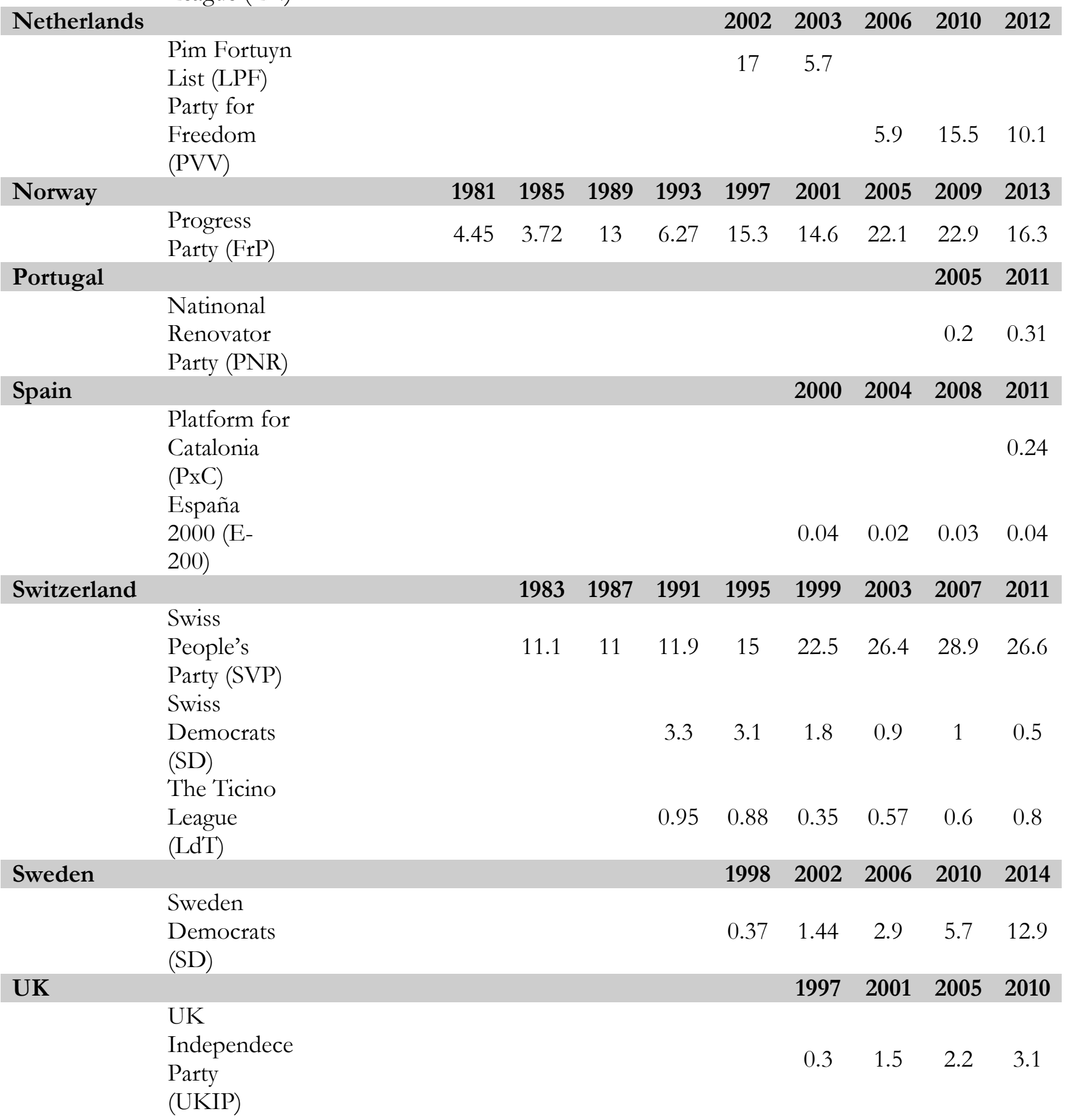

Source: Own elaboration based on official electoral data from each country 


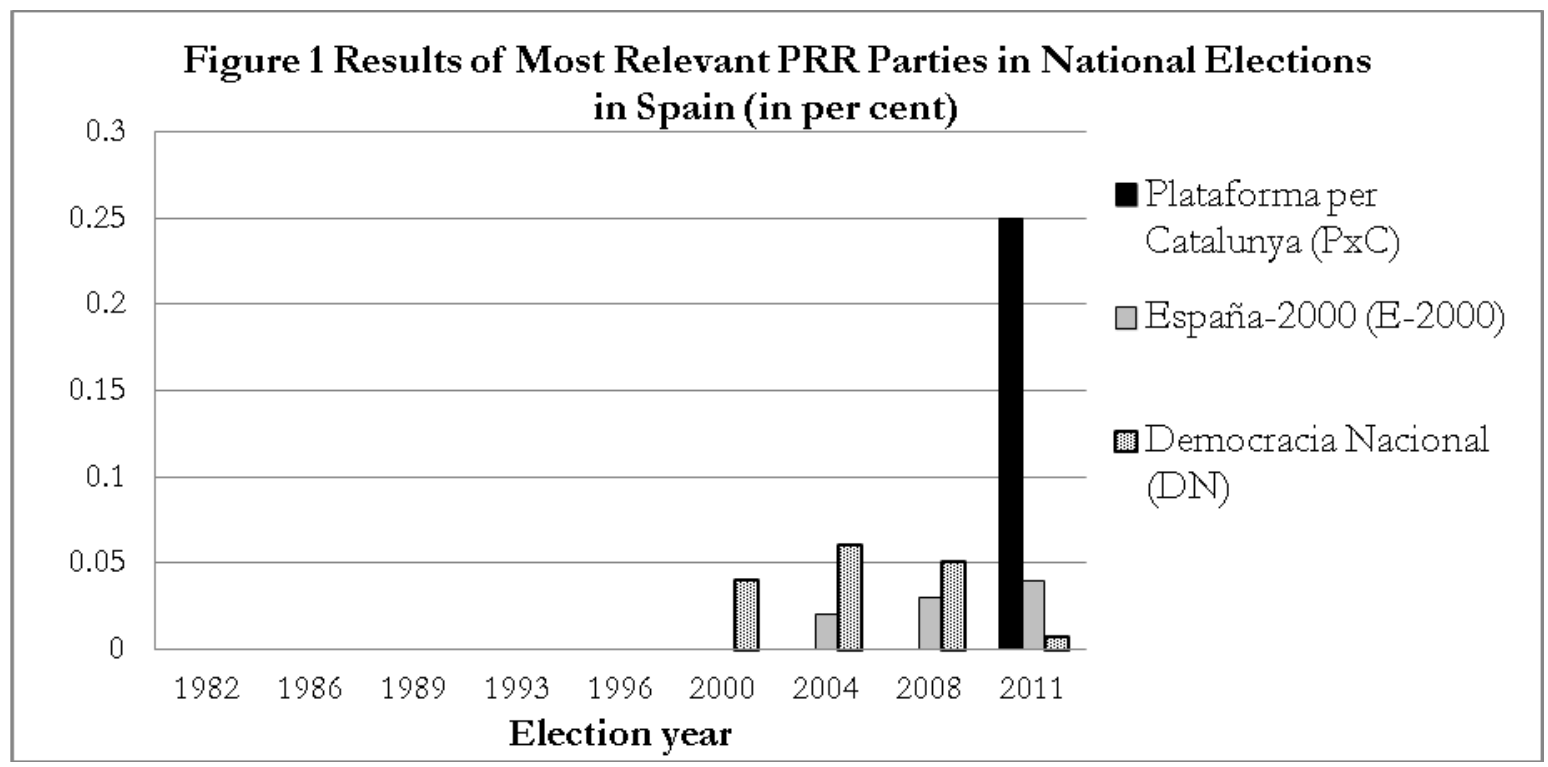

Source: Own elaboration with official electoral data from the Spanish Ministry of the Interior 


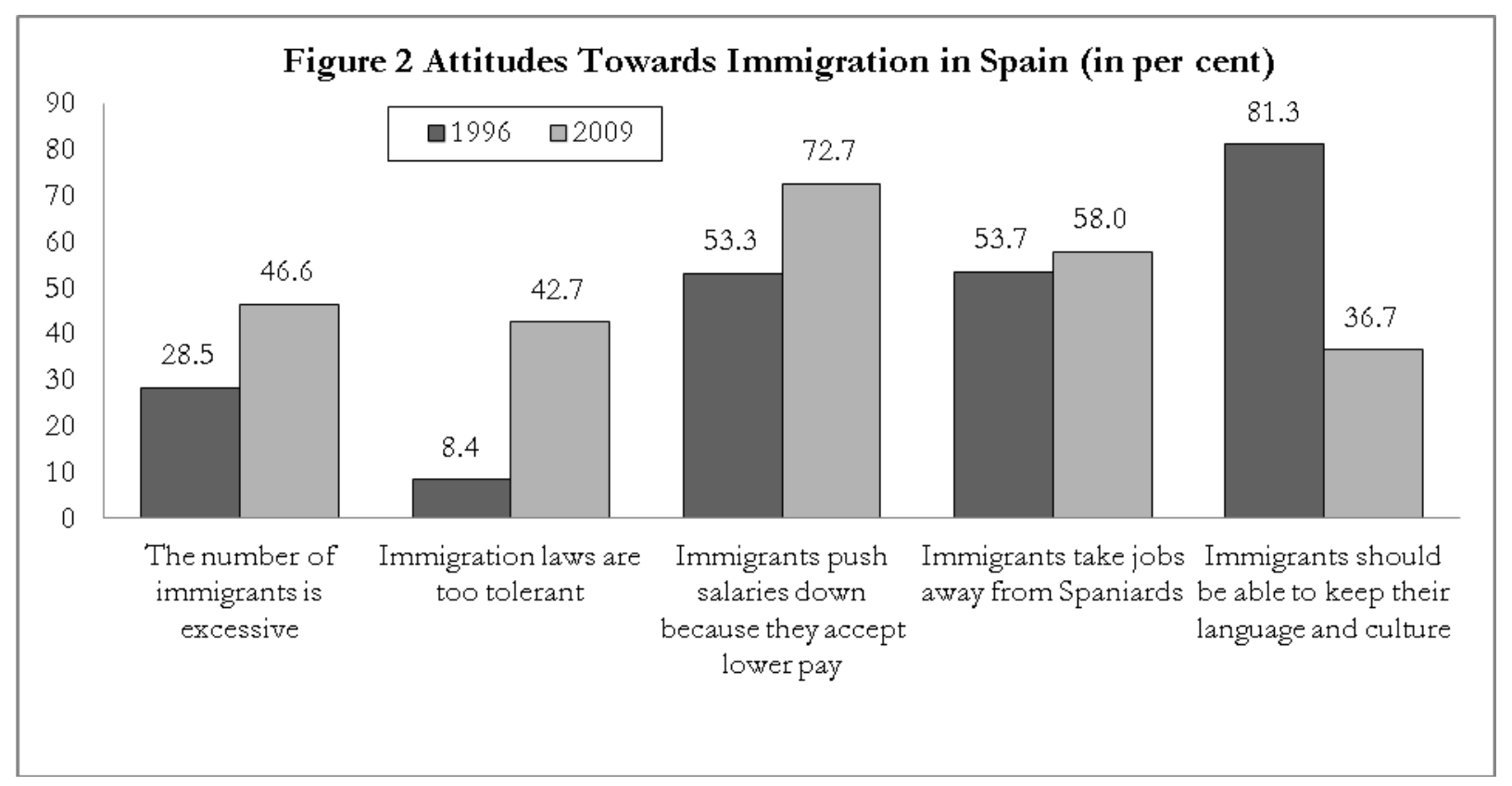

Source: Own elaboration on the basis of CIS surveys 2214 (1996) and 2817 (2009) 
Figures $3 \& 4$ Trust in Democratic Institutions and Satisfaction with Democracy, Spain and European Mean Values between 2002 and 2012 (Eurobarometer ${ }^{1}$ )

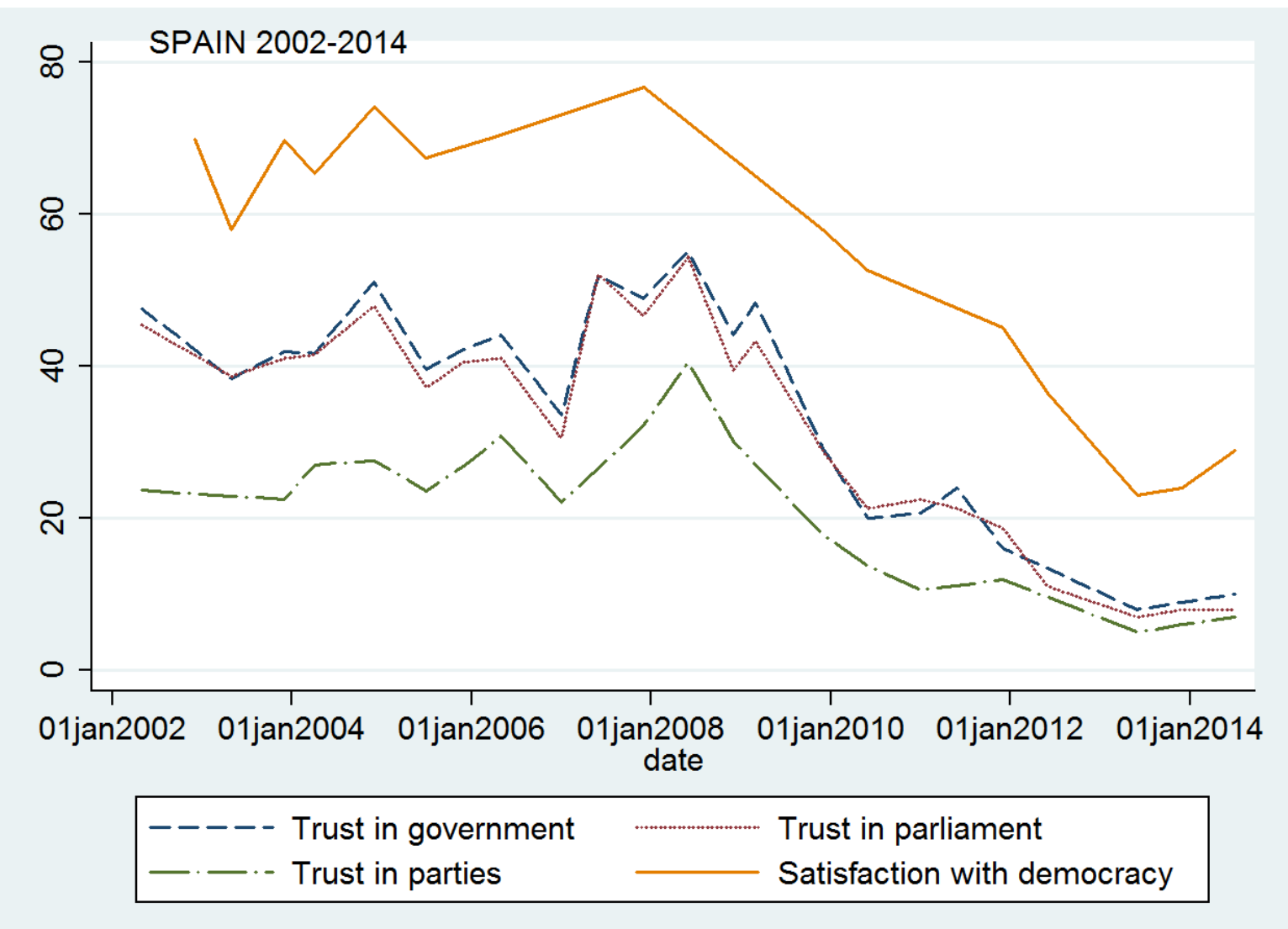

Source: Own calculations based on Eurobarometer data between 2002 and 2014.

\footnotetext{
${ }^{1}$ Trust is measured as the percentage of respondents that claim to trust the institution. Satisfaction with democracy is measured as the percentage of respondents that claim to be very or fairly satisfied with democracy.
} 


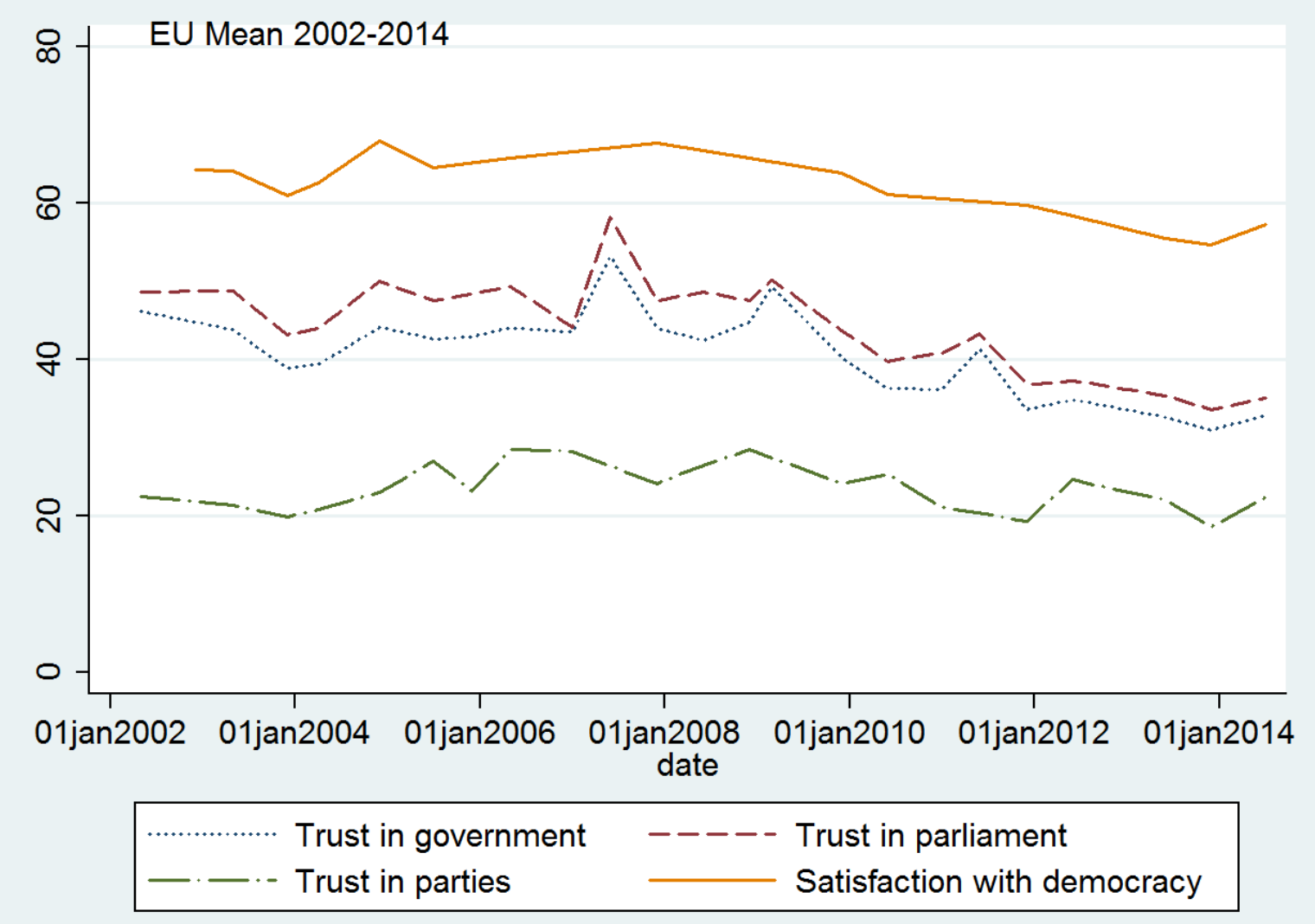

Source: Own calculations based on Eurobarometer data between 2002 and 2014. 


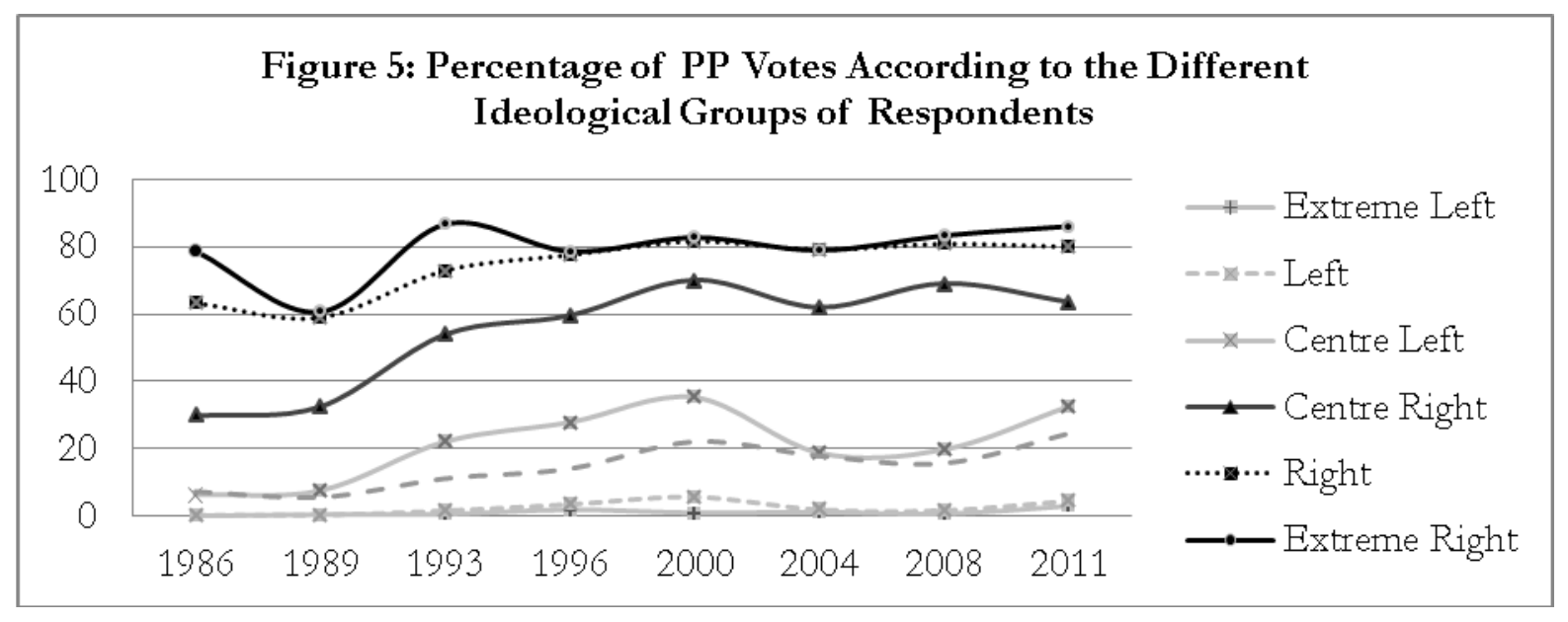

Source: Own elaboration on the basis of de la Calle et al. (forthcoming) 
Table 2 Percentage of Party Manifestos' Sentences Dedicated to Socio-Economic, Centre-

Periphery and Immigration Issues Across Time in Spain (1979-2011)

\begin{tabular}{|c|c|c|c|c|}
\hline Election year & $\begin{array}{c}\text { Market liberalism } \\
\text { vs. government } \\
\text { intervention }\end{array}$ & $\begin{array}{c}\text { Welfare state } \\
\text { pro- and con- }\end{array}$ & Centre-periphery & $\begin{array}{c}\text { Immigration } \\
\text { pro- and con- }\end{array}$ \\
\hline 1979 & 7.6 & 13.9 & 10.9 & 3.7 \\
\hline 1982 & 8.7 & 14.2 & 9.3 & 2.9 \\
\hline 1986 & 7.9 & 12.2 & 11.2 & 2.5 \\
\hline 1989 & 6.6 & 13.5 & 9.7 & 3.4 \\
\hline 1993 & 7.3 & 11.6 & 11.7 & 5.1 \\
\hline 1996 & 4.6 & 8.5 & 11.6 & 5.1 \\
\hline 2000 & 4.7 & 9.9 & 13.2 & 5.2 \\
\hline 2004 & 2.8 & 10.7 & 11.6 & 4 \\
\hline 2008 & 3.7 & 10.7 & 11.9 & 2.5 \\
\hline 2011 & 7.4 & 11.7 & 3.8 \\
\hline Mean $(1979-2011)$ & 6 & 11.9 & 10.7 & 3.6 \\
\hline
\end{tabular}

Source: Own elaboration based MARPOR project: https://manifesto-project.wzb.eu/ 


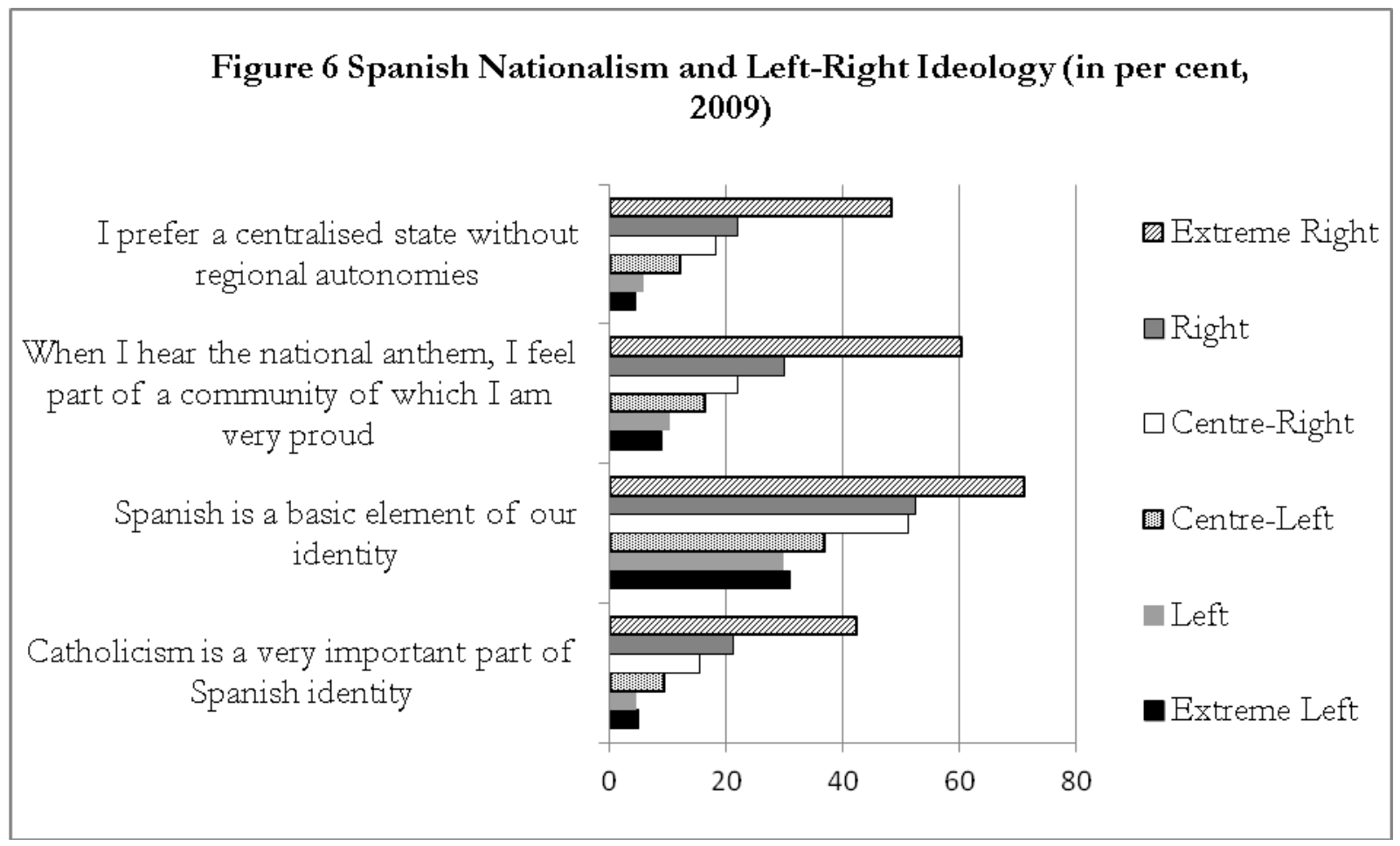

Source: CIS 2667 (2009)

1 Previous versions of this paper were presented at the World Conference of the International Political Association (IPSA) held in Madrid, July 8-12, 2012, and at the Research in Progress Seminar of the Sussex European Institute, February 6, 2013. For their valuable comments on earlier drafts, we are indebted to Tim Bale, Cas Mudde, Paul Taggart, the two anonymous reviewers and the editors of South European Politics \& Society. Cristóbal Rovira Kaltwasser wants to acknowledge that the research leading to these results has received funding from the European Community's Seventh Framework Program (FP7/20072013) under grant agreement PIEF-GA-2010273525 and the Chilean National Fund for Scientific and Technological Development (FONDECYT project 1140101).

2 Own calculations with official electoral data from the Ministry of the Interior.

3 Data from the Spanish Ministry of Employment and Social Security: extranjeros.empleo.gob.es.

4 Immigrants without legal residence can and normally do register as residents with the local authorities in order to be eligible for social services.

5 Data from the Spanish Ministry of Employment and Social Security: extranjeros.empleo.gob.es.

6 The year 2012 is the last for which ESS data are available.

7 Data from Eurobarometer, November 2001.

8 Data from the European Social Survey 2010.

9 Unfortunately, these questions were part of a one-time questionnaire that has not been replicated later on. For this reason we cannot present more recent data.

10 Variable labels are as follows: "ipfrule", "ipstrgv" and "iprspot", respectively.

11 The median values of the distribution are, respectively, 3.2, 2.3 and 3.1, and Spain's mean positions are 3.3, 2.1 and 3.5 respectively. 
12 Source: Database 'Elections, Parties, Governments' of the Research Unit Demokratie Forschung at the Social Science Research Center Berlin (WZB).

${ }^{13}$ For a similar argument applied to the case of Germany, see Bornschier (2012). 